\title{
Total Information Score, Multivariate Analysis and Usefulness of Agricultural Knowledge and Information of Irrigation Farmers in North Western Nigeria
}

\author{
Lawal Iro Sani' ${ }^{1}$ Umar Maiwada ${ }^{2}$ \\ ${ }^{1}$ Department of Library and Information Science, Umaru Musa Yar'adua University, Katsina State, Nigeria \\ ${ }^{2}$ Department of Library and Information Science, Hassan Usman Katsina Polytechnic, Katsina State, Nigeria \\ Email: lawaliros@yahoo.com,maiwada_umar@yahoo.com
}

How to cite this paper: Sani, L.I. and Maiwada, U. (2018) Total Information Score, Multivariate Analysis and Usefulness of Agricultural Knowledge and Information of Irrigation Farmers in North Western Nigeria. Open Access Library Journal, 5: e3132.

https://doi.org/10.4236/oalib.1103132

Received: October 12, 2016

Accepted: April 23, 2018

Published: April 26, 2018

Copyright $\odot 2018$ by authors and Open Access Library Inc.

This work is licensed under the Creative Commons Attribution International License (CC BY 4.0).

http://creativecommons.org/licenses/by/4.0/

\begin{abstract}
Any system producing or containing information intended for transmission is an information source. This study examines the use of multivariate statistical analysis and total information score for information sources of irrigation farming in North western Nigeria. A questionnaire survey of 368 household was used to explore the impact of information sources in accessing agricultural information by irrigation farmers. Three States were studied using qualitative and quantitative research approach. The results of the study revealed that irrigation farmers in the study area opted to use information emanating from public and private sources. The results further reveal that there is a strong positive linear relationship between agricultural information needs of irrigation farmers and the sources of that information. The study therefore, suggested that in order to fill the information gaps of the irrigation farmers, more sources should be explored and be made available to the irrigation farmers.
\end{abstract}

\section{Subject Areas \\ Information Science}

\section{Keywords}

Multivariate, Irrigation Farming, Private Information Sources, Public Information Sources, Information Needs, North Western Nigeria

\section{Introduction}

A principal component which is concern with explaining the variance-covariance 
structure of a set of variables through a few linear combinations of these variables is usually referred to as multivariate. Therefore, its general objectives are Data reduction and Interpretation. Multivariate statistics provides the ability to analyze complex set of data. For instance, there are many independent variables (IVs), and possible dependent variables (DVs), which are correlated to each other to varying degrees (Osborne, 2002) [1]. Any system producing or containing information intended for transmission is an information source. Information sources, according to Feather \& Sturges (2004) [2], are distinguished by the form of representation, textual (books, journals, manuscripts), graphics (graphs, diagrams, plan charts), and audiovisuals (sound recordings, motion pictures, slides). Therefore, the characteristics of good information sources are relevance, timeliness, accuracy, accessibility, cost effectiveness, reliability, usability, exhaustiveness and aggregation levels (Feather \& Sturges, 2003). Oladele (1999) [3] stresses that the efficiency of technologies generated and disseminated depend on effective communication which is the key process of information dissemination. Therefore, it is expected that the message from the client should be passed back to the source or researchers for the communication process to be complete. Despite the attempts at technological innovation transfer, the wide gap between the levels of production which research contends is attainable and that which farmers achieve, suggests a missing link (Oladele, 1999). What is more, weak linkages between the farmer, extension workers and researchers mean that farmers are not included in the planning of the innovation, hence they do not know where to get information despite the fact that they are the end users. Agricultural information disseminated by different information sources needs to be determined. It is imperative therefore to identify the sources of agricultural information.

Opara (2008) [4] investigated the overall sources of agricultural information available to farmers in Imo State (Nigeria), as well as the farmers' preferred sources. The study revealed that $88.1 \%$ of the farmers' source of agricultural information was through extension agents. Similarly, Ozowa (2008) [5] shows that among all the existing channels of communication, Nigerian farmers ranked extension workers the highest in providing credible information and advice. The investigation was carried out on small farmers in Imo state, Nigeria.

Mokotjo \& Kalusopa (2010) [6] found out that print sources are among the sources of information to farmers in Lesotho. Their study revealed that though most of the farmers have acquired primary education, the agricultural information delivered to them is written in local languages. This enables them to utilize the information effectively. It also demonstrates the high literacy level in Lesotho and according to the literacy rate in Africa, Lesotho occupies the seventh position with a literacy rate of $84.80 \%$ (Aneki, 2012) [7]. However, only $13 \%$ out of $61.7 \%$ of the farmers in Lesotho are of the view that prints media is one of the appropriate technologies to disseminate information. However, Lwoga, Stilwell \& Ngulube (2011) [8] significantly differ from Mokotjo \& Kalusopa (2010). For 
them, print materials have low usage due to their unavailability and illiteracy levels of most of the farmers in Tanzania.

Mass media also provides support for the growing involvement of farmers/producers and their organizations in the information dissemination arena. The rapid development of information technologies has profoundly changed the media landscape in African countries. Information and Communication Technology (ICT) is a term that combines computer and telecommunications technology in handling, acquiring, processing, storing and disseminating information (Chauhan, 2009; and Malhan, 2007) [9] [10]. Information and Communication Technology is a general or an all-inclusive term that embraces all those technologies that are employed in collecting, storing, organizing and communicating information in various forms (Chisita, 2010) [11]. ICT can become a key enabler of the agricultural-food sector by making dynamic and real time global level exchange of data. As stated by Rao (2009: p. 492) [12], "Effective deployment of ICT can lead to increase in agricultural competitiveness through cuts in production and transaction costs, raising production efficiencies and farm incomes, conserving natural resources, and by providing more information, choice and value to stakeholders". In using ICT successfully to support farmers and rural communities, the first step is to empower farming communities to define their own needs (Ballantyne, 2009: p. 356) [13]. With wider access to and use of ICT, the potentials of opening up of communication as well as sharing information would be enhanced so as to assist farmers, researchers, extension workers and policy makers. It will also narrow the information gap that exists between farmers and the researchers because there will be a feedback (Ballantyne, 2009). Similarly, Renwick (2010) [14], pointed out that most of the small island nations are above the $100 \%$ or with some over $200 \%$ mobile phone penetration mark. This implies that many people had more than one cell phone and over $100 \%$ of the farmers used cell phones to receive agricultural information.

This indicates that ICT is a very useful tool in the dissemination of agricultural information to farmers especially in rural areas where cell phones have been embraced by both literate and illiterate farmers. Therefore ICT has become the most important tool in processing and disseminating agricultural information. In the same vein Bolarin \& Ayanlade (2010) [15] maintained that mobile phones and computer systems are the most used and widely owned tools today by extension workers and their organizations. This is because, about $75 \%$ of the respondents surveyed by Bolarin \& Ayanlade (2010) perceived themselves as frequent users of multimedia and other ICT tools.

Other sources of information that are equally important, but less recognized are traditional sources. These include information emanating from colleagues, during weddings, naming ceremonies, burials, agricultural shows and festivals and in some cases through town criers (Aina, 1995) [16]. Demiryurek et al. (2008) [17] argue that dairy farmers in Turkey use four categories of information all of which are traditional and relayed from family members. They are: extension workers, posters and leaflets, family members and the electronic media. 
In the Caribbean, farmers rely heavily on traditional knowledge and informal meetings among themselves for (Renwick, 2010). Questions as to what to plant, what moon phase is best for sowing seeds and transplanting seedlings, and how often to rotate crops are answered through colleague discussion. This suggests that, one of the sources of information for farmers in the Caribbean is the traditional source which is transmitted through oral channels by colleagues. This is similar to the situation obtainable in Nigeria as reported by Aina (1995). Similarly, Opara (2008) reported that agricultural information in its broadest sense includes indigenous agricultural knowledge (IAK) which is transmitted orally. This is a very common practice in Nigeria and is hugely relied on by old farmers as well as the illiterate and many others who favour oral dissemination of information. Oral tradition is an important method of disseminating agricultural information in many African cultures because it recognizes existing traditional or indigenous channels of information dissemination.

Lwoga et al. (2011) in their study on access and use of agricultural information and knowledge in Tanzania reported that the major sources of information for farmers are predominantly local (neighbours, friends and family) meaning that they are traditional. To emphasize the importance of traditional information in Africa, Aina (1995) points out that one of the sources of information for farmers in Nigeria is traditional. That is, information obtained not from official sources directly but through colleagues or family members. Aina holds the view that though the majority of the farmers in Africa are illiterate, it is possible to supply them with necessary information through information gate- keepers popularly known in North Western Nigeria as SARKIN RAFI (Information gate keeper), this is a literate farmer among the farming community with a wealth of experience and vast land. The role of a $S A R K I N R A F I$ is to offer advice and information on a regular basis to other farmers for improvement. In a study conducted on access to agricultural information by fish farmers in the Niger Delta Region of Nigeria, Ugboma (2010) [18] buttresses the various studies cited when she observes that $63 \%$ of the respondents indicated that their source of information is traditional, as well as personal experience.

\section{Objectives of the Study}

1) To identify the different sources of information available.

2) To examine whether these sources of information were adequately utilized by the respondents group;

3) To identify the relationship between information needs of the respondents and access to the sources of information.

4) And to identify the gaps that exists in accessing information through these sources.

\section{Methodology}

The methodology used in this study was the survey research method in which 
quantitative and qualitative approach was used. In other words, the mixed research method was used. A population of 368 households were studied.

\section{Findings:}

\section{Main Sources of Information}

There is a wide range of information sources. However, four sources were the most common sources of information for the irrigation farmers. These are personal information, public information sources, private information sources and mass media and there is an association between these categories of information sources. Personal sources include farmers to farmers, friends and relatives. Public information includes extension workers, researchers and educators. Private information sources are NGOs, agro-allied industries and private consultants, while mass media include radio, television, projector and slides.

Figure 1 shows the main sources of information for irrigation farmers. In this study, 105 (28.5\%) irrigation farmers indicated that their main source of information was the electronic media. Electronic media, in the context of this study refers to programmes on agriculture that are aired through radio and television either weekly or fortnightly. Another set of 174 (47.2\%) respondents indicated that their main source of information was extension workers, while 17 (4.6\%) indicated that their main sources of information were newspapers and magazines. Furthermore, $38(10.3 \%)$ respondents stated that ICT tools were their sources of information, while $26(7.0 \%)$ mentioned books as their main source of information. The other $8(2.2 \%)$ respondents stated journals to be their main source of information.

In order to properly link the sources of information extension workers used to disseminate agricultural information to the irrigation farmers, extension workers were asked what their main sources of information were. From the responses, 27 (37.5\%) respondents indicated that their main sources of information were government documents. These are publications emanating directly from government, for example, white paper, magazines and monthly reports dealing with agricultural issues. Another 14 (19.4\%) extension workers indicated that their main sources of information were the research results usually generated from universities and research institutes. Also, 5 (6.9\%) extension workers indicated

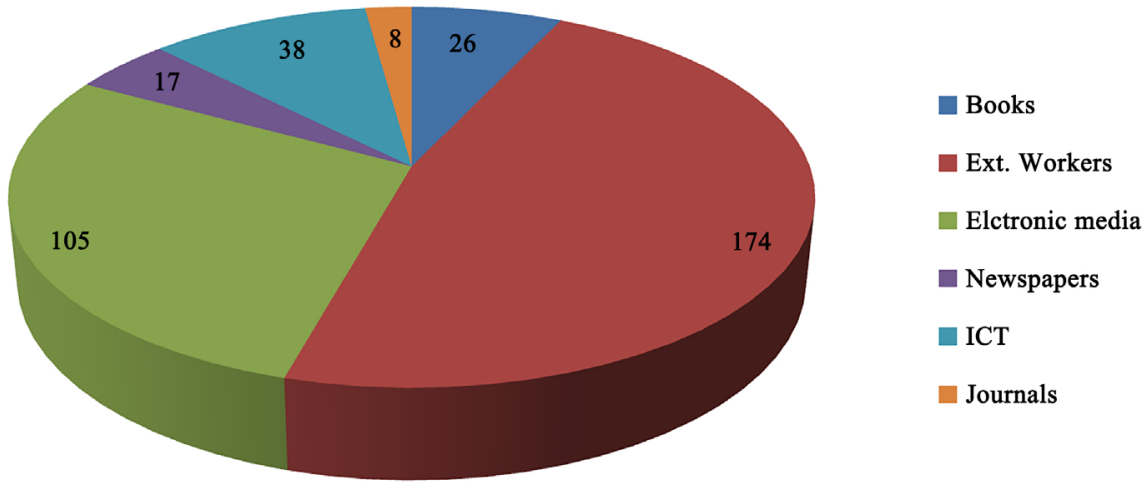

Figure 1. Information for irrigation farmers. 
that their sources of information were online sources and ICT tools, which include computers, internet and Global System for Mobile Communication (GSM) cell phones. Another 18 (25.0\%) extension workers indicated that their sources of information were books and journals, while 8 (11.1\%) indicated their sources of information to be multimedia or electronic media. Such types of resources are radio, television, projectors and slides. While interviewing extension workers on what were the main sources of information for irrigation farmers, all the 72 $(100 \%)$ indicated extension workers, newspapers, magazines, journal, books and ICT tools.

From the cross tabulation made and based on the regression analysis it was found out that three most significant factors affecting access to and adoption of information, in descending order of their significance, were information contact, source of information and usefulness of information in irrigation farming. In this study, sources of information had a significant relationship with agricultural knowledge and information systems. The cross tabulation made on the main source of information with agricultural knowledge and information justified the relationship between these variables as shown in Table 1 .

From the cross tabulation made between the main source of information for irrigation farmers and their agricultural information and knowledge needs for irrigation farming, Table 1 shows that the number of valid cases is 368 , the Pearson Chi square $\chi^{2}$ value is 30.479 . The calculated $p$-value is 24.995 , the degree of freedom is 15 and the Asymp. Sig. (2-sided) is 0.010. The likelihood ratio value is 31.374 and the linear-by-linear association is 12.912 . The result of this cross tabulation implies that the $p$-value is greater than 0.05 and therefore, the main source of information determines the agricultural information and knowledge needed for irrigation farming. Thus, there is a significant relationship between the main source of information and agricultural knowledge and information needs of irrigation farmers.

Table 1. Main source of information with agricultural knowledge and information needed for irrigation farming $(\mathrm{N}=368)$.

\begin{tabular}{|c|c|c|c|c|c|c|}
\hline $\begin{array}{l}\text { Main source } \\
\text { of information }\end{array}$ & $\begin{array}{l}\text { Scientific type of } \\
\text { information }\end{array}$ & $\begin{array}{c}\text { Commercial type of } \\
\text { information }\end{array}$ & $\begin{array}{l}\text { Legal type of } \\
\text { information }\end{array}$ & $\begin{array}{l}\text { Scientific and } \\
\text { commercial }\end{array}$ & Total & Chi-square Value \\
\hline Journals & $7(87.5 \%)$ & $1(12.5 \%)$ & $0(0.0 \%)$ & $0(0.0 \%)$ & $8(100 \%)$ & Missing values \\
\hline $\begin{array}{l}\text { Electronic } \\
\text { media }\end{array}$ & $59(57.3 \%)$ & $30(29.1 \%)$ & $8(7.6 \%)$ & $8(7.6 \%)$ & $105(100 \%)$ & Missing values \\
\hline Extension workers & $68(39.5 \%)$ & $68(39.5 \%)$ & $15(8.6 \%)$ & $23(13.2 \%)$ & $174(100 \%)$ & Missing values \\
\hline Total & $176(48.5 \%)$ & $119(32.8 \%)$ & $26(7.06 \%)$ & $46(12.4 \%)$ & $368(100 \%)$ & $\mathrm{X}^{2}=30.479$ \\
\hline
\end{tabular}


In this study, one of the variables information sources, was observed to have outliers as seen in Figure 2. The appearance of outliers may either positively or negatively skew the result of the study unless a data transformation is done to correct the anomaly. Data transformation is the application of a mathematical modification to the value of a variable. There are a great variety of possible data transformations, from adding a constant to multiplying, squaring or raising to a power (Osborne, 2002). Thus, one reason researchers utilised data transformation is to improve the normality, kurtosis, negative skewness and outliers from the data sets that can alter estimates of the variable. In this study, the outliers were removed by adjusting the affected variables (squaring) until skeweness and kurtosis are nearest to zero and also to conform to the Gausian probability Function using - log base 10 SPSS.

\section{Irrigation Farmers' Perceived Ease of Access to Information}

The issue of access to information was central to understanding the extent of information utilization in irrigation farming. For ease of access to information obtained, irrigation farmers were asked to indicate how easily they retrieved information. Farmers were asked multiple questions which require multiple answers. Table 2 shows a score of $46(12.5 \%)$ respondents who indicated that they found it very easy to find information. A huge 251 (68.0\%) respondents indicated that they found it easy to locate information from the main source. On the contrary, 23 (6.2\%) respondents indicated that it was not easy for them to locate and have access to information. This implied that it had been very difficult for them to access information.

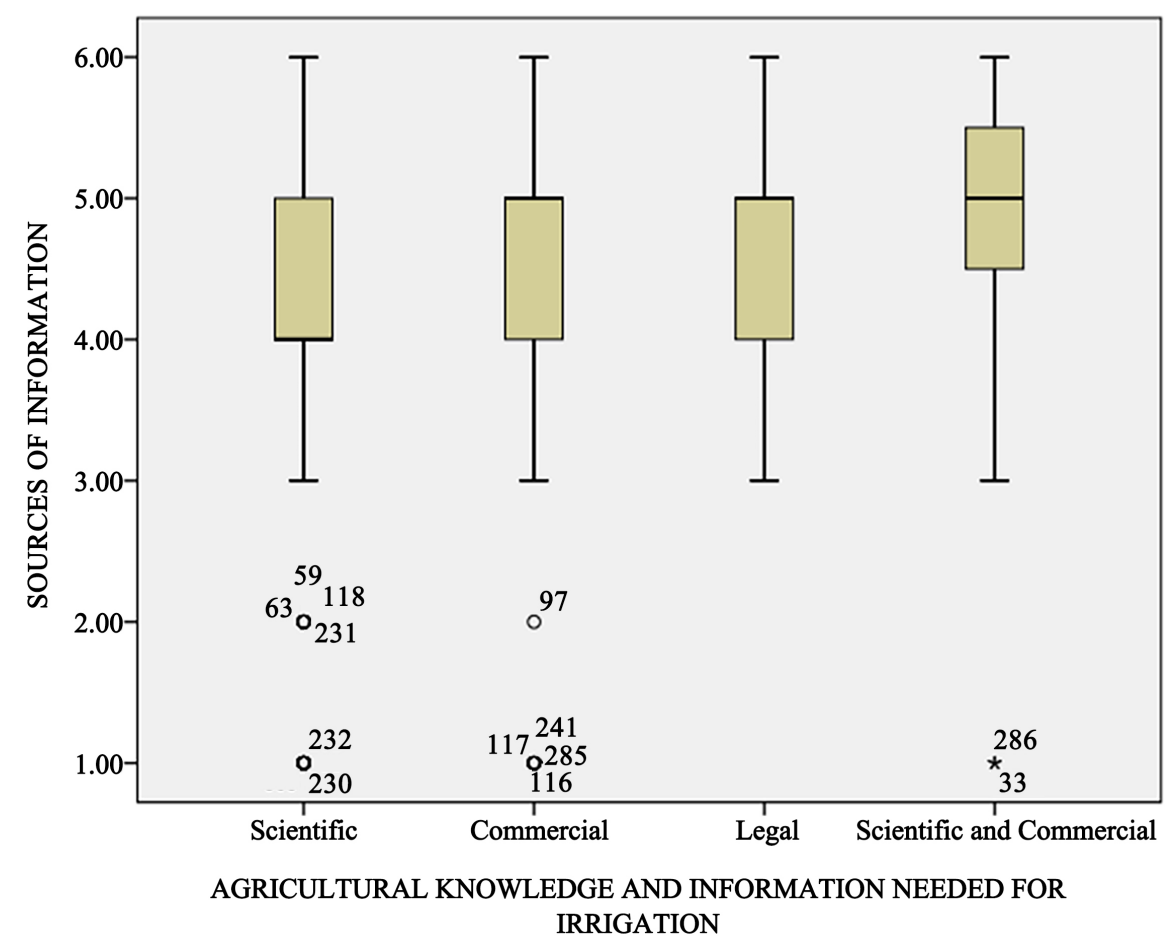

Figure 2. Normality test for sources of information (Source: field survey, 2014). 
Table 2. Perceived ease of access to information $(\mathrm{N}=676)$.

\begin{tabular}{ccc}
\hline Ease of access and level & Frequency & Percentages \\
\hline Very easy & 46 & $12.5 \%$ \\
Easy & 251 & $68.0 \%$ \\
Not easy & 23 & $6.2 \%$ \\
Strongly disagree & 24 & $6.5 \%$ \\
Disagree & 47 & $12.7 \%$ \\
Strongly agree & 93 & $25.2 \%$ \\
Agree & 192 & $52.0 \%$ \\
Total & 676 & $183.2 \%$ \\
\hline
\end{tabular}

The respondents were also asked questions which required such specific answers as "agree", "disagree" or "strongly agree". Table 2 explains the level of access to information by irrigation workers. In the study, 24 (6.5\%) respondents indicated that they strongly disagreed that access to information was reliable and the sources helped in irrigation farming, while 47 (12.7\%) respondents disagreed that access to information was reliable and the sources helped in irrigation farming. In addition, $93(25.2 \%)$ respondents indicated that they strongly agreed that access to information was reliable and the sources helped in irrigation farming. Other $192(52.0 \%)$ respondents indicated that they agreed that access to information was reliable and the sources helped in irrigation farming. The responses in this case were divided at the level of access to information and whether it was useful or not. The results showed that accessibility to agricultural knowledge and information was very poor.

Irrigation Farmers Contact with Information Sources

In order to explain the extent of contact and usefulness, the respondents were asked to specify the various channels of information with their frequency of contact (both receiving and giving information, that is the source and the irrigation farmers who are the end users). The channels of information and technology exchange in this context are the means through which irrigation farmers receive from or give information to the main source (feedback). Under each of these information and technology sources are many information channels which were grouped under personal information sources, public information sources, private information sources and mass media (Demiryurek, 2000) [19]. According to Demiryurek, et al. (2008), the score value for the frequency of contact and the weighted values of the usefulness of the information source were used to calculate the total information score as:

$$
\begin{aligned}
\text { TIS }= & \text { number of contact } \times \text { usefulness of information } \\
& \text { Total Information Score } \text { Sco }_{i j}=F C_{i j} \times I U_{i j}
\end{aligned}
$$

where $F C$ is the number of contacts with information sources for the $i$-irrigation farming and $I U$ is the usefulness of information for irrigation farming. The 
weights were given to each component according to the extent of information contact. The weight of 0 was given to no contact, 1 for once a year, 2 for two or three times a year, 4 for four or five times a year, 12 for once a month, 30 for two or three times a month, 52 for once a week, 130 for two or three times a week and 365 for information contacts once a day. Therefore, the degree of information contact can be categorized into different groups according to information scores of each information source and its usefulness. These methods of presenting the multiple choice question would provide a positive correlation in order to increase the validity of the measurement. Table 3 provides a tabular presentation of the weighted values of information contact, sources of information and usefulness of information.

The dissemination and adoption of improved farming techniques by the farmer require efficient mechanisms for the acquisition of farm inputs and equipment. As the name implies, farm or agricultural inputs are items farmers add to farm resources in order to enhance productivity, stability or continuity. The most commonly used agricultural inputs include fertilizers, other agrochemicals, sprayers and improved seeds. In order for the irrigation farmers to get access to these inputs and information on how to get them, they must have priority on the type of information they needed and the level of contact they had with the information providers. Table 3 depicts that information.

\section{Conclusion and Recommendation}

Based on the findings from this study, it was gathered that sources of information to irrigation farmers in North Western Nigeria was very important in determining their information needs. It should therefore be noted that information is the basic requirement for knowledge and for development. Having access to knowledge and information through an effective and efficient source is a fundamental right of every irrigation farmer. Hence, this study recommended some measures to be taken in order to rescue irrigation farmers from taking the wrong decision due to ineffective and inefficient sources of information.

Table 3. Agricultural knowledge and information needs of irrigation farmers with level of the information contact with sources (extension workers) $(\mathrm{N}=368)$.

\begin{tabular}{ccccccc}
\hline $\begin{array}{c}\text { Types of } \\
\text { information } \\
\text { needed }\end{array}$ & $\begin{array}{c}\text { Level of } \\
\text { a week }\end{array}$ & $\begin{array}{c}\text { Level of } \\
\text { contact twice } \\
\text { in a month }\end{array}$ & $\begin{array}{c}\text { Level of } \\
\text { contact once a } \\
\text { month }\end{array}$ & $\begin{array}{c}\text { Level of } \\
\text { contact } \\
\text { sometimes }\end{array}$ & Total & $\begin{array}{c}\text { Chi square } \\
\text { value }\end{array}$ \\
\hline Commercial & $41(30.8 \%)$ & $0(0.0 \%)$ & $0(0.0 \%)$ & $92(69.2 \%)$ & 133 & $\begin{array}{c}\text { Missing } \\
\text { values }\end{array}$ \\
Legal & $0(0.0 \%)$ & $37(67.3 \%)$ & $18(32.7 \%)$ & $0(0.0 \%)$ & 55 & $\begin{array}{c}\text { Missing } \\
\text { values }\end{array}$ \\
Scientific & $0(0.0 \%)$ & $0(0.0 \%)$ & $168(47.2 \%)$ & $0(0.0 \%)$ & 168 & $\begin{array}{c}\text { Missing } \\
\text { values }\end{array}$ \\
Total & $41(11.5 \%)$ & $37(10.0 \%)$ & $186(52.2 \%)$ & $92(25.8 \%)$ & $356(96.7 \%)$ & $\mathrm{X}^{2}=572.314$ \\
\hline
\end{tabular}




\section{Effective and Timely Radio Broadcast}

Poor timely radio broadcast and signals were identified as part of the bottlenecks in having access to information. Hence, efforts should be made to ensure that broadcast time for radio programmes is sufficient, appropriate, timely, and clear and that wide coverage is made possible. Transmission signals must always be strong. This is because it has been observed that farmers prefer radio as one of their suitable technologies for retrieval of information. Agricultural broadcast which covers various aspects of agricultural production activities at different times of the year should be made more accessible to irrigation farmers by removing all possible obstacles. The farm broadcast should cover several farming activities such as agro-forestry, agro-processing, agro-marketing, crop production and protection.

\section{Effective Deployment of ICT Facilities}

Access to ICT facilities was identified to be a hindrance in having access to information by both irrigation farmers and extension workers. Therefore, an effective ICT facility should be made available and accessible. There is need to emphasize the acquisition of persuasive communication skills by extension workers to enable them to function effectively as change agents and in aiding irrigation farmers to acquire theoretical as well as practical experience. Also, the need for training and re-training of extension workers and irrigation farmers on ICT is paramount so as to bridge the digital divide. Training will update and enhance the capacity of the EWs to utilize ICTs and other tools for food security.

\section{Provision of Effective Library Services}

Despite the fact that the majority of the irrigation farmers were illiterate and don't have time to visit the library, there is need to strengthen the available agricultural libraries. There is need to establish a functional and efficient library in State Ministries of Agriculture to enable policy makers, researchers, teachers, students, extension workers and literate farmers to have access to up-to date and accurate agricultural knowledge and information. Gray literature, especially conference proceedings, annual, research and technical reports should be collected, organized and bibliographically controlled since these documents are very difficult to locate and retrieve.

\section{Provision of Sufficiently Trained Extension Workers}

The provision of sufficiently trained extension workers is paramount. The government at all levels should embark on the recruitment of trained extension workers who are versed in agricultural science, information technology and management, and who are capable of using modern techniques in information resource management. The extension workers should be given the chance to receive training and re-training so that they could acquaint themselves with new innovation, knowledge and information. The sustainability of such training and re-training is very important and should be funded adequately. The type and level of training depend on the readiness of the agricultural information centres (ministries), user-researcher, extension workers and rural irrigation farmers and policy makers. This is because the lack of articulated agricultural information 
user training down to the grass-root level has often impeded the dissemination of agricultural information to the farmers.

\section{References}

[1] Osborne, J. (2002) Notes on the Use of Data Transformation. Practical Assessment Research and Evaluation, 8, 1-7.

[2] Feather, J. and Sturges, P., Eds., (2003) International Encyclopedia of Information and Library Science. 2nd Edition, Routledge, New York.

[3] Oladele, O.I. (1999) Extension Communication Methods for Reaching Small-Ruminant Farmers in South Western Nigeria. Proceedings of the 26 th Annual Nigerian Society of Animal production Conference, Ilorin, 20-25 June 1999.

[4] Opara, U.N. (2008) Agricultural Information Sources Used by Farmers in Imo State, Nigeria. Information Development, 24, 289-292.

https://doi.org/10.1177/0266666908098073

[5] Ozowa, V.N. (2008) Information Needs of Small Scale Farmers in Africa: The Nigerian Example. Quarterly Bulleting of the International Association of Agricultural Information Specialist, 40, 1-6.

[6] Mokotjo, W. and Kalusopa, T. (2010) Evaluation of the Agricultural Information Service (AIS) in Lesotho. International Journal of Information Management, 30, 350-356. https://doi.org/10.1016/j.ijinfomgt.2010.01.005

[7] Aneki.com (2012) List of Countries with the Highest Literacy Rates in Africa.

[8] Lwoga, E., T, Stilwell, C. and Ngulube, P. (2011) Access and Use of Agricultural Information and Knowledge in Tanzania. Agricultural Information and Knowledge. Library Review, 60, 383-395. https://doi.org/10.1108/00242531111135263

[9] Chauhan, A.V. (2009) Use of ICT (Information and Communication Technology) in Technology Libraries. Journal of Library Philosophy and Practice, 2, 1-16.

[10] Malhan, I.V. (2007) Agricultural Knowledge Transfer in India: A Study of Prevailing Communication Channels. Journal of Library Philosophy and Practice, 1-12.

[11] Chisita, C.T. (2010) An Investigation into the Use of ICT in the Provision of Agricultural Information to Small Scale Farmers in Harare. World Library and Information Congress. Proceedings of the 76th IFLA General Conference and Assembly, Gothenburg, 1-14.

[12] Rao, N.H. (2007) A Frame Work for Implementing Information and Communication Technologies in Agricultural Development in India. Journal of Technological Forecasting and Social Change, 74, 491-518. https://doi.org/10.1016/j.techfore.2006.02.002

[13] Ballantyne, P. (2009) Accessing, Sharing and Communicating Agricultural Information for Development: An Emerging Trends and Issues. Information Development, 25, 260-271. https://doi.org/10.1177/0266666909351634

[14] Renwick, S. (2010) Current Trends in Agricultural Information Services for Farmers in Trinidad and Tobago. Proceedings of the 76th IFLA, General Conference and Assembly, Gothenburg, 1-12.

[15] Bolarin, O. and Ayanlade, A. (2010) Utilization of Satellite Imaging and Information Communication Technology in Agricultural Information Dissemination in Nigeria. Journal of Agricultural and Food Information, 11, 351-357. https://doi.org/10.1080/10496505.2010.520987

[16] Aina, L.O. (1995) Information and Agriculture in Africa. In: Aina, L.O., Kaniki, 
A.M. and Ojiambo, J.B., Eds., Agricultural Information in Africa, Third World Information Services, Ibadan.

[17] Demiryurek, K., Erdem, H., Ceyhan, V., Atasar, S. and Uysal, O. (2008) Agricultural Information Systems and Communication Network: The Case of Dairy Farmers in the Samsun Province of Turkey. Information Research, 13, 1320.

[18] Ugboma, M.U. (2010) Access to Agricultural Information by Fish Farmers in Niger Delta Region of Nigeria. Journal of Library Philosophy and Practice, 17, 1-18.

[19] Demiryurek, K. (2000) The Analysis of Information Systems for Organic and Conventional Hazelnut Products in Three Villages of the Black Sea Region, Turkey. Published Doctoral Dissertation. Submitted to University of Reading, Reading, UK. http://www.informationr.net/ir/13-2/paper343.html 